\title{
IRISH-LANGUAGE EDUCATION AND THE COUNCIL OF EUROPE'S MINORITY TREATIES: THE MONITORING OF DEVELOPMENTS IN NORTHERN IRELAND
}

\author{
Dr. Elizabeth Craig, Lecturer in Law, University of Sussex*
}

\section{Introduction}

Like many other minority languages in Europe, the Irish language suffered considerable decline during the $20^{\text {th }}$ Century ${ }^{1}$ and the development of Irishmedium education has been a particular priority of the Irish-language revival movement. $^{2}$ The first Irish-medium primary school was established in Northern Ireland in 1971, followed by the first Irish-medium secondary school twenty years later. ${ }^{3}$ Although English is the normal language of communication in Northern Ireland, the Irish language is considered by many to be an important part of their cultural heritage $e^{4}$ and an increasing number of English-speaking parents are choosing to send their children to Irish-medium schools. ${ }^{5}$ The role of education in promoting tolerance and understanding was specifically recognised in the Good Friday Agreement of $1998,{ }^{6}$ which envisaged the placing of a statutory duty on the Department of Education to encourage and facilitate the development of Irish-medium education, ${ }^{7}$ a duty subsequently introduced through legislation. ${ }^{8}$ By that time the UK had already ratified the Council of Europe's Framework Convention for the Protection of National Minorities $1995^{9}$ and was giving "active consideration" to the signing of the European Charter for Regional or

* With thanks to Professor Craig Barker, Professor Marie Dembour, Professor Sue Millns and an anonymous referee for their comments on earlier drafts.

1 Hindley, The Death of the Irish Language: A Qualified Obituary (1990).

2 O'Reilly, The Irish Language in Northern Ireland: The Politics of Culture and Identity (1999), p.22.

3 Mercator-Education, Irish - The Irish Language in Education in Northern Ireland $2^{\text {nd }}$ ed. (2004) http://www1.fa.knaw.nl/mercator/regionale_dossiers/PDFs/irishnorth.pdf (2 February 2007), pp.18 and 21.

4 In the 2001 Census $10.35 \%$ of all persons aged three and over in Northern Ireland declared that they had some knowledge of Irish. $4.64 \%$ declared that they could speak, read, write and understand Irish. (Northern Ireland Statistics and Research Agency 'Census 2001 Output' http://www.nisranew.nisra.gov.uk/Census /Census2001Output/KeyStatistics/keystatrep.html (2 February 2007) Table KS24: Knowledge of Irish).

5 Mercator-Education, supra n.3 at 3.

6 'Agreement Reached in the Multi-party Negotiations (10 April 1998)' http://www.nio.gov.uk/agreement.pdf (2 February 2007) 'Rights, Safeguards and Equality of Opportunity' para.13 (on integrated education) \& 'Economic, Social and Cultural Issues' paras.3-4 (on linguistic diversity and Irish-medium education). 7 ibid.. at para.4.

8 S.89 Education (Northern Ireland) Order 1998 SI 1998/1759.

9 'Framework Convention for the Protection of National Minorities CETS No.: 157' $\mathrm{http} / / /$ conventions.coe.int/Treaty/Commun/ChercheSig.asp?NT=157\&CM=7\&DF= 2/2/2007\&CL=ENG (2 February 2007). 
Minority Languages $1992 . .^{10}$ Both of these treaties deal extensively with minority-language education issues and therefore appeared to be particularly relevant for the development of Irish-language education in Northern Ireland.

Whilst there is an ever-increasing body of commentary on both the Framework Convention and the Languages Charter, ${ }^{11}$ much less has been written about the relationship between the two treaties ${ }^{12}$ and their particular implications for minority-language education in the UK. ${ }^{13}$ This article therefore aims to use the UK's experiences in relation to Irish-language education to explore further the relationship between the two treaties. The article begins by examining the failure of the UN human rights treatymonitoring bodies to address Irish-language education issues under the core human rights treaties, despite the concerns raised by civil society. The article then considers the extent to which the Council of Europe's minority treaties provide a more appropriate framework for the consideration of such issues. Although both treaties were considered together to form part of a new "regime of linguistic promotion" in Europe, ${ }^{14}$ this article argues that they have very different roles in relation to the protection of indigenous and non-indigenous languages and of the speakers of those languages. The article focuses in particular on differences in their scope of application and in their normative content and uses the UK's experiences in relation to Irishlanguage education in Northern Ireland to illustrate the significance of the differences in approach.

\section{Irish-Language Education and the UN Human Rights Treaties}

Although issues relating to minority-language education have occasionally been addressed under the UN human rights treaty framework, particularly in relation to the right to education, ${ }^{15}$ the situation of Irish-language education

10 Supra n.7.

11 See, for example, Council of Europe (ed), Filling the Frame: Five Years of Monitoring the Framework Convention for the Protection of National Minorities (2004); Weller (ed.), The Rights of Minorities: A Commentary on the Framework Convention for the Protection of National Minorities (2005); Oeter, 'The European Charter for Regional or Minority Languages' in Council of Europe Publishing (ed.) Mechanisms for the Implementation of Minority Rights (2004) 131 and Woehrling, The European Charter for Regional or Minority Languages: A Critical Commentary (2005).

12 For an early analysis of the different approaches in the two treaties, see Dunbar, 'Minority Language Rights in International Law' (2001) 50 ICLQ 90.

13 However, see Williams and Rainey, 'Language, Education and the European Convention on Human Rights in the Twenty-First Century' (2002) 22 LS 625. On the more general implications of the Charter for linguistic minorities in the UK, see Dunbar, 'Implications of the European Charter for Regional or Minority Languages for British Linguistic Minorities' (2000) 25 EL Rev Supp 46. On debates in Northern Ireland over the scope of the Framework Convention, see McCrudden 'Consociationalism, Equality and Minorities in the Northern Ireland Bill of Rights Debate: The Role of the OSCE High Commissioner on National Minorities' in Morison, McEvoy and Anthony (eds.), Judges, Transition and Human Rights 2007 p.315.

14 Dunbar, supra n.12 at 92.

15 E.g. 'Concluding Observations of the Committee on Economic, Social and Cultural Rights: Estonia. 19/12/2002' UN Doc. E/C.12/1/Add.85 at paras.32 and 57 (expressing concern about the lack of opportunities for being educated in 
in Northern Ireland has not been addressed by the relevant treaty monitoring bodies on a consistent basis, despite the voicing of concerns by civil society. The Committee on the Administration of Justice ${ }^{16}$ in its submission to the Committee on the Rights of the Child in 1994 expressed concern that government policy in relation to the funding of Irish-medium education was discriminatory. ${ }^{17}$ In response the committee suggested that the UK provide further support for the teaching of the Irish language in schools but notably did not recommend the provision of further support for Irish-medium education. ${ }^{18}$ At the time the committee appeared much more interested in strategies to promote integration amongst Roman Catholic and Protestant children in Northern Ireland, ${ }^{19}$ recommending that the State party provide further support for integrated education. ${ }^{20}$ This reflects a more general trend evident also in the focus on the development of integrated education in the later concluding observations of both the Committee on the Rights of the Child and the Committee on Economic, Social and Cultural Rights. ${ }^{21}$ This trend can be attributed not only to the intercultural educational aims identified in both the International Covenant on Economic, Social and Cultural Rights 1966 and the UN Convention on the Rights of the Child $1989^{22}$ but also to a general perception that segregation in education had

minority languages in Estonia); 'Concluding Observations of the Committee on the Rights of the Child: Latvia. 21/02/2001' UN Doc. CRC/C/15/Add.142 at paras.51-52 (expressing concern about plans to provide secondary legislation in Latvian only) and 'Concluding observations of the Committee on the Elimination of Racial Discrimination: France. 18/04/2005.' UN Doc. CERD/C/FRA/CO/16 at para.23 (expressing concern about shortcomings in the teaching of certain minority languages).

16 The Committee on the Administration of Justice is an independent NGO in Northern Ireland.

17 CAJ 'Report for consideration during the Committee's scrutiny of the UK Government's report, 1 August 1994' http://www.crin.org/docs/resources /treaties/crc.8/UK_Committee_NGO_Report.pdf (2 February 2007) Education Arts. 28-29.

18 'Concluding observations of the Committee on the Rights of the Child: United Kingdom of Great Britain and Northern Ireland. 15/02/95.' UN Doc. CRC/C/15/Add.34 at para.33.

19 E.g. CRC Committee 'List of Issues: United Kingdom of Great Britain and Northern Ireland. 20/10/94.' UN Doc. CRC/C.8/WP.1 Q 36: “. . . What strategies are being developed to promote greater integration amongst children from the different communities?"

20 'Concluding observations of the Committee on the Rights of the Child: United Kingdom of Great Britain and Northern Ireland. 15/02/95.' UN Doc. CRC/C/15/Add.34 at para.33.

21 'Concluding observations of the Committee on Economic, Social and Cultural Rights: United Kingdom of Great Britain and Northern Ireland. 04/12/97.' UN Doc. E/C.12/1/Add.19 at para.29; 'Concluding observations of the Committee on Economic, Social and Cultural Rights: United Kingdom of Great Britain and Northern Ireland. 05/06/2002.' UN Doc. E/C.12/1/Add.79 at para.42 and 'Concluding observations of the Committee on the Rights of the Child: United Kingdom of Great Britain and Northern Ireland. 09/10/2002.' UN Doc. CRC/C/15/Add. 188 at para.48(g).

22 Art. 29(1) UNCRC and Art. 13(1) ICESCR. 
contributed to the prolonged conflict between the two main communities in Northern Ireland. ${ }^{23}$

Despite the lack of concrete recommendations from the UN treatymonitoring bodies, the Irish-medium education sector expanded considerably in the 1990s in response to increased parental demand with the same procedures being used to determine State funding as those used in relation to English-medium schools. ${ }^{24}$ By 2002-03 there were 18 Irish-medium primary schools in Northern Ireland, five of which were fully funded by the State and seven of which received State funding for recurrent expenditure only. Seven Irish-medium units in English-medium primary schools at that time received funding from the State. ${ }^{25}$ In the same year funding was also provided to Meanscoil Feirste, the first Irish-medium secondary school, and to two Irishmedium secondary units. ${ }^{26}$ The UK was therefore able to report a number of positive developments in its second report submitted under the UNCRC in 2002, including the fact that four Irish-medium primary schools and the Irish-medium secondary school had been given grant-aided status in the previous three years, that provision had been made for GCSE examinations to be taken in Irish and that a unit had been established to provide teaching materials for use in Irish-medium schools. ${ }^{27}$

There nevertheless remains a growing demand for Irish-medium education and, in its submission to the Committee on the Rights of the Child in 2002, the Northern Ireland Human Rights Commission observed that "adequate support has yet to be provided to ensure the right of parents to have their children educated in an Irish-medium or integrated school". ${ }^{28}$ The Commission recognised that more funding had been provided but observed in particular that schools had to fulfil very strict funding criteria and that it could be difficult for children to access transport services and special needs provision while schools were awaiting approval of their status. ${ }^{29}$ The Commission therefore requested information from the Government on how it intended to ensure that children attending Irish-medium and integrated schools were not discriminated against in terms of access to funding. ${ }^{30}$ In a similar vein, in its submission to the Committee on Economic, Social and Cultural Rights one month later, the Commission noted that there had been a "substantial improvement" in the provision of Irish-medium education but considered that additional funding should be provided to redress "historic underfunding of many schools" and to meet the start-up costs of new

23 E.g. 'Summary record of the 38th meeting: United Kingdom of Great Britain and Northern Ireland. 28/11/97.' UN Doc. E/C.12/1997/SR.38 at para.62.

24 'Summary record of the 206th meeting: United Kingdom of Great Britain and Northern Ireland. 03/07/95.' UN Doc. CRC/C/SR.206 at para.33 and 'Fourth periodic report: United Kingdom of Great Britain and Northern Ireland. 28/02/2001.' UN Doc. E/C.12/4/Add.8 at paras.13.124 - 13.125.

25 Mercator-Education, supra n.3 at 18.

26 ibid. at 21.

27 'Periodic reports of States parties due in 1998: United Kingdom of Great Britain and Northern Ireland. 25/02/2002.' UN Doc. CRC/C/83/Add.3 at para. 9.47.

28 NIHRC, 'Submission to the United Nations Committee on the Rights of the Child, March 2002' http://www.nihrc.org/documents/landp/79.doc (5 June 2006) at 4.

$29 \mathrm{ibid}$. at 39.

30 ibid at 40. 
schools. ${ }^{31}$ Despite the Commission's concerns, neither committee made recommendations in relation to Irish-language education in the last reporting cycle. This suggests that such issues are not a particular priority of the UN treaty-monitoring bodies, especially where a majority language is the normal language of communication and there are no obvious individual rights violations. As both the Framework Convention and the Languages Charter contain provisions on minority-language education, they appeared to provide a much clearer legal basis for challenging State policy in this area. However, important differences in the scope of application and the normative content of these two treaties have had a significant influence on the outcome of the relevant monitoring processes.

\section{Differences in the Scope of Application of the Two Treaties}

Although the Framework Convention and the Languages Charter both came into force early in $1998,{ }^{32}$ the initiative for the adoption of the Charter was taken in the 1980s, ${ }^{33}$ "at a time when the problem of minorities was not on everybody's lips", ${ }^{34}$ and reflected a general concern "to protect the linguistic diversity of Europe" rather than the pursuit of a minority rights agenda. ${ }^{35}$ It is therefore aimed at the protection of regional or minority languages rather than the protection of linguistic minorities ${ }^{36}$ and was not intended to establish any individual or collective rights for language speakers. ${ }^{37}$ However, as noted by Oeter, it is clear that the imposition of obligations on the State in relation to the protection of such languages "might give rise in consequence to subjective rights in the internal legal sphere." 38

According to the Explanatory Report, the "overriding purpose" of the Languages Charter was "to protect and promote regional or minority languages as a threatened aspect of Europe's cultural heritage". ${ }^{39}$ One consequence of this is that the Languages Charter covers only those languages "traditionally used within a given territory of a State by nationals of that State who form a group numerically smaller than the rest of the State's population" and expressly excludes the languages of migrants. ${ }^{40}$ The

31 NIHRC, 'Submission by the Northern Ireland Human Rights Commission to the United Nations Committee on Economic, Social and Cultural Rights, April 2002' http://www.nihrc.org/documents/landp/80.doc (5 June 2006) at paras.5(e) and (f).

32 The Framework Convention (ETS 157) was opened for signature 1 February 1995 and came into force 1 February 1998. The Languages Charter (ETS 148) was opened for signature 5 November 1992 and came into force 1 March 1998.

33 On the history, see Grin, Language Policy Evaluation and the European Charter for Regional or Minority Languages (2003), pp.57-58.

34 Krüger, 'Opening address' in International Conference on the European Charter for Regional or Minority Languages, Strasbourg, 26-27 March 1998 (1998), p.7 at 9.

35 PACE Opinion No.142 (1988) on Resolution 192 (1988) on regional or minority languages in Europe, adopted by the Standing Conference of Local and Regional Authorities of Europe (4 October 1988).

36 'Explanatory report' in European Charter for Regional or Minority Languages and explanatory report (1993) 3 at para. 11.

37 ibid.

38 Oeter, supra n.11 at 131.

39 'Explanatory report', supra n.36 at para. 10.

40 Art. 1(a). 
drawing of such a distinction supports Dunbar's assertion that the Languages Charter reflects an "ecological" as opposed to an "identity" approach to language rights, ${ }^{41}$ based on comparisons made between threats to linguistic diversity and threats to biodiversity. ${ }^{42}$ One of the arguments used by those who draw such comparisons is that linguistic diversity is a public good, the production costs of which should be fairly distributed. ${ }^{43}$ Such an approach can be used to support language preservation policies and provides an alternative to the notion of language as "a central and defining feature of identity", which is often associated with a rights-based approach. ${ }^{44}$

The Framework Convention was the Council of Europe's response to the political upheaval in Central and Eastern Europe after the end of the Cold War ${ }^{45}$ and the immediate concern of the drafters was the situation of autochthonous minorities in Central and Eastern Europe. ${ }^{46}$ However, the drafters decided "to adopt a pragmatic approach" to the definitional issue "based on the recognition that at this stage, it is impossible to arrive at a definition capable of mustering general support of all Council of Europe member States." 47 There were initial concerns about the failure of the drafters to define the term "national minority" 48 and many States did respond by adopting a very restrictive approach in relation to its scope of application. ${ }^{49}$ However, the lack of a definition can also be used by those

41 Dunbar, supra n.12 at 95.

42 E.g. Skutnabb-Kangas, Linguistic Genocide in Education - or Worldwide Diversity and Human Rights? (2000), pp.63-97.

43 Boran, 'Global Linguistic Diversity, Public Goods, and the Principle of Fairness' in Kymlicka and Patten (eds.), Language Rights and Political Theory (2003), p.189. On the intrinsic value of languages as collective human accomplishments and as manifestations of human creativity, see Réaume, 'Official-Language Rights: Intrinsic Value and the Protection of Difference' in Kymlicka and Norman (eds.), Citizenship in Diverse Societies (2000), p.245.

44 Patten and Kymlicka 'Introduction: Language Rights and Political Theory: Context, Issues and Approaches' in Kymlicka and Patten (eds.), Language Rights and Political Theory (2003), p.1 at 45.

45 'Vienna Declaration of the Heads of State and Government of the Member States of the Council of Europe on the Reform of the Control Mechanism of the ECHR, on National Minorities, and on a Plan of Action against Racism' (1993) 14 HRLJ 373

46 Malloy describes an "autochthonous minority" as "a minority that is native to a particular region, in this case certain regions of Europe that were once either independent or belonged to a neighbouring state. The autochthonous minority's present minority status is a result of incorporation into a larger political unit or the change of borders after major conflicts in modern times." (Malloy National Minority Rights in Europe (2005) p.21)

47 'Explanatory report' in Framework Convention for the Protection of National Minorities: Collected texts (1999) 17 at para.12.

48 E.g. Alfredsson, 'A Frame for an Incomplete Painting: Comparison of the Framework Convention for the Protection of National Minorities with International Standards and Monitoring Procedures' (2000) 7 IJMGR 291 and Benoît-Rhomer, The Minority Question in Europe. Texts and Commentary (1996), p.41.

49 E.g. Denmark, Netherlands, Slovenia, Sweden and the Former Yugoslav Republic of Macedonia. See 'List of declarations made with respect to treaty No.: 157' $\mathrm{http} / / /$ conventions.coe.int/Treaty/Commun/ListeDeclarations.asp?NT=157\&CM=7 $\& \mathrm{DF}=2 / 2 / 2007 \& \mathrm{CL}=\mathrm{ENG} \& \mathrm{VL}=1$ (2 February 2007). 
advocating a more inclusive approach, particularly as Article 1 makes it clear that the protection of national minorities is considered to be "an integral part of the international protection of human rights." 50 For example, Keller has argued that immigrant minorities should have an equal claim to the benefits of the Framework Convention on the basis that the "right to maintain and develop a cultural identity ${ }^{51}$ is in principle a universal right." 52 The UK appeared to adopt such an approach in its first report under the Framework Convention, which purported to be based on the definition of a racial group in the Race Relations Act 1976 as "a group of persons defined by reference to colour, race, nationality or ethnic or national origins". 53 However, this approach is also flawed as this definition does not cover groups defined exclusively by language or religion. ${ }^{54}$ Whilst it was clearly intended that the Irish language would be protected under the Languages Charter, ${ }^{55}$ the extent to which Irish-language speakers would be protected under the Framework Convention was less clear. The next section argues further that, despite some substantive overlap, there are also important normative differences between the two treaties.

\section{Differences in the Normative Framework}

The Framework Convention has been described as "a weak first attempt" at guaranteeing minority rights in Europe ${ }^{56}$ with criticisms directed towards the failure to confer rights on groups, the emphasis on the obligations of the State at the expense of the rights of the individual, the weak wording of the substantive provisions and the envisaged enforcement system. ${ }^{57}$ Of course the problem, as identified by Keller, is that human rights treaties, in order to be effective, "must reflect sound, coherent principles, but must also stay within the bounds of political acceptability." 58 It was clear from the outset that the norms adopted would have to be sufficiently flexible to accommodate a range of minority groups and situations and the focus is

50 On the inclusive approach to the definitional issue adopted by the Advisory Committee on the Framework Convention, see Wheatley Democracy, Minorities and International Law (2005) pp.48-56.

51 Art. 5(1) of the Framework Convention specifically requires States "to promote the conditions necessary for persons belonging to national minorities to maintain and develop their culture, and to preserve the essential elements of their identity".

52 Keller, 'Re-thinking Ethnic and Cultural Rights in Europe' (1998) OJLS 29, at 43.

53 S.3(1) Race Relations Act 1976 (UK) c.74. See 'Report submitted by the United Kingdom pursuant to Article 25, paragraph 1 of the Framework Convention for the Protection of National Minorities' ACFC/SR(1999)013 (26 July 1999) at para.2.

54 Dunbar, 'Is There a Duty to Legislate for Linguistic Minorities?' (2006) 33 J Law \& Soc 181, at 186-187.

55 Supra n.7.

56 Gilbert, 'The Council of Europe and Minority Rights' (1996) 18 HRQ 160 at 189.

57 E.g. Alfredsson, supra n.48; Benoît-Rhomer, supra n.48, pp.38-51; Gilbert, supra n.56; Packer, 'On the Content of Minority Rights' in Räikkä (ed.), Do We Need Minority Rights? (1996), p.121 at 159-161 and Troebst, The Council of Europe's Framework Convention for the Protection of National Minorities Revisited, ECMI Working Paper 2 (1998).

58 Keller, supra n.52 at 57. 
notably on the identification of objectives which the Parties undertake to pursue rather than the creation of directly applicable rights. ${ }^{59}$

Whilst the Framework Convention contains norms of general application, the approach under the Languages Charter is quite different. Although Part II of the Charter applies to all regional or minority languages spoken within a State's territory, States can choose which languages to register under Part III and undertake to apply a minimum of thirty-five paragraphs or subparagraphs from among the sixty-eight provisions in Part III "in respect of each language specified at the time of ratification, acceptance or approval." 60 This "à la carte system" was initially considered to be one of the Charter's main weaknesses, ${ }^{61}$ although Oeter has noted that one of the advantages of such an approach is that the obligations contained therein are more precise and concrete than the "programme-type provisions"62 in the Framework Convention. ${ }^{63}$

As minority-language education is considered to play a particularly important role in the preservation of cultural identity and the maintenance of cultural diversity, the rest of this section will focus on the wording of the substantive norms on education. These reveal the particular limitations of the Framework Convention's approach and provide a clear indication of the desire of the drafters "to stay within the bounds of political acceptability". ${ }^{64}$ For example, Article 13(1) requires States to "recognise that persons belonging to a national minority have the right to set up and to manage their own private educational and training establishments" but Article 13(2) qualifies this considerably by providing that: "The exercise of this right shall not entail any financial obligation for the Parties." In a similar vein Article 14(1) requires States "to recognise that every person belonging to a national minority has the right to learn his or her minority language" but the Explanatory Report makes it clear that it was not intended that this obligation would require "positive action, notably of a financial nature, on the part of the State." 65 The positive obligations of the State in relation to minoritylanguage education therefore appear to be restricted to Article 14(2), which notably avoids the use of rights language and provides in highly qualified terms that:

"In areas inhabited by persons belonging to national minorities traditionally or in substantial numbers, if there is sufficient demand, the Parties shall endeavour to ensure, as far as possible and within the framework of their education systems, that persons belonging to those minorities have adequate opportunities for being taught the minority language or for receiving instruction in this language."

Furthermore there is an additional qualification in Article 14(3), which stipulates that paragraph 2 "shall be implemented without prejudice to the

\footnotetext{
59 'Explanatory report', supra n 47 at para.11.

60 Art.2(2).

61 E.g. Benoît-Rhomer, supra n.48 at 51.

62 'Explanatory report', supra n.47 at para.11.

63 Oeter, supra n.11 at 135.

64 Supra n.58.

65 'Explanatory report', supra n.47 at para.74.
} 
learning of the official language or the teaching in this language". Such knowledge is identified in the Explanatory Report as "a factor of social cohesion and integration" 66 but commentators have cautioned that this provision should not be used to limit the rights of persons belonging to national minorities "to learn or be instructed in their language." Unsurprisingly, the wording of these provisions has been criticised. For example, Article 13(2) has been described as "bleak" and "draconian"68 and it has also been observed that Article 14(2) does not provide a very strong legal basis for action. ${ }^{69}$

Similar issues are dealt with under the Languages Charter but the use of rights-language is avoided altogether and the obligations accepted by States are more concrete. In relation to those languages protected under Part III of the Charter, States must choose a minimum of three options from the paragraphs and sub-paragraphs in Article 8 on education..$^{70}$ The undertakings in Article 8(1) relate to the different stages of education and apply "within the territory in which such languages are used, according to the situation of each of these languages, and without prejudice to the teaching of the official language(s) of the State". In relation to primary education, States can choose from the following options in Article 8(1)(b):

"(i) to make available primary education in the relevant regional or minority languages; or

(ii) to make available a substantial part of primary education in the relevant regional or minority languages; or

(iii) to provide, within primary education, for the teaching of the relevant regional or minority languages as an integral part of the curriculum; or

(iv) to apply one of the measures provided for under i to iii above at least to those pupils whose families so request and whose number is considered sufficient;"

Similar options are available in relation to secondary education and to technical and vocational education but the last option is "to apply one of the measures provided for under $\mathrm{i}$ to iii above at least to those pupils who, or where appropriate whose families, so wish in a number considered sufficient". ${ }^{71}$ Other undertakings in Article 8 relate to the provision of preschool education, ${ }^{72}$ higher education ${ }^{73}$ and adult and continuing education courses ${ }^{74}$ the making of arrangements "to ensure the teaching of the history and the culture which is reflected by the regional or minority language" 75 and the provision of the basic and further training of teachers required to

66 ibid. at para.78.

67 De Varennes and Thornberry, 'Article 14' in Weller (ed.), supra n.11, p.407 at 428.

68 Thornberry 'Article 13' in Weller (ed.), supra n.11, pp.395 at 404 \& 405.

69 Supra n.67 at 427.

70 Art. 2(2).

71 Art. 8(1)(c) and (d).

72 Art. 8(1)(a).

73 Art. 8(1)e).

74 Art. 8(1)(f).

75 Art. 8(1)(g). 
implement the obligations accepted. ${ }^{76}$ In respect of territories other than those in which the regional or minority languages are traditionally used, Parties can also undertake under Article 8(2) "to allow, encourage or provide teaching in or of the regional or minority language at all the appropriate stages of education" if the number of users justifies it. States may also undertake under Article 8(1)(i) to set up a supervisory body to monitor "the measures taken and progress achieved in establishing or developing the teaching of regional or minority languages and for drawing up periodic reports of their findings, which will be made public."

As a consequence of its focus on linguistic diversity and the preservation of minority languages, the Languages Charter places considerable emphasis on "the value of interculturalism and multilingualism". ${ }^{77}$ This is particularly evident in Article 7, which is in Part II of the Charter and therefore applies in respect of all regional or minority languages spoken within the territory. ${ }^{78}$ In relation to education, Article 7(1) provides that:

"In respect of regional or minority languages, within the territories in which such languages are used and according to the situation of each language, the Parties shall base their policies, legislation and practice on the following objectives and principles: ...

the provision of appropriate forms and means for the teaching and study of regional or minority languages at all appropriate stages;

the provision of facilities enabling non-speakers of a regional or minority language living in the area where it is used to learn it if they so desire..."

The Explanatory Report makes it clear that the "spirit of receptiveness to several languages should not be confined to the speakers of regional or minority languages" and that the latter requirement was included "to facilitate communication and understanding" and "to ensure greater mutual permeability" between language groups. ${ }^{79}$ Article 7(3) further requires States to promote mutual understanding between linguistic groups ${ }^{80}$ and particular emphasis is placed in the Explanatory Report on the role that the development of a spirit of receptiveness and tolerance can play in the preservation of such languages. ${ }^{81}$

Such ideas are not completely neglected under the Framework Convention and the Preamble stresses "that the creation of a climate of tolerance and

76 Art. 8(1)(h).

77 Preamble, para.5.

78 Art. 2(1).

79 Explanatory report' in European Charter for Regional or Minority Languages and explanatory report (1993) at paras.65-66.

80 Art. 7(3): "The Parties undertake to promote, by appropriate measures, mutual understanding between all the linguistic groups of the country and in particular the inclusion of respect, understanding and tolerance in relation to regional or minority languages among the objectives of education and training provided within their countries and encouragement of the mass media to pursue the same objective."

81 'Explanatory report', supra n.79 at para.74. 
dialogue is necessary to enable cultural diversity to be a source and a factor, not of division, but of enrichment for each society". 82 Article 12(1) is specifically aimed at the creation of such a climate, ${ }^{83}$ providing that: "The Parties shall, where appropriate, take measures in the fields of education and research to foster knowledge of the culture, history, language and religion of their national minorities and of the majority." The need for intercultural education initiatives, defined as "educational policies and practices by which the members of different cultures, whether in a majority or minority position, learn to interact constructively with each other", ${ }^{84}$ is more specifically recognised in Article 12(2), which provides that: "In this context the Parties shall inter alia provide adequate opportunities for teacher training and access to textbooks, and facilitate contacts among students and teachers of different communities." Meanwhile Article 12(3) requires States "to promote equal opportunities for access to education at all levels for persons belonging to national minorities." The Framework Convention is more specific than the Languages Charter about what States are required to do to promote intercultural education and it is fairly unsurprising that Article 12 has been more favourably received in the literature than Articles 13 and 14. ${ }^{85}$

There is clearly considerable substantive overlap between the Framework Convention and the Languages Charter and, despite clear normative differences, both treaties essentially defer to the discretion of individual States on matters relating to the provision and funding of minority education. This discretion is conferred on States through the weak wording of the provisions on education in the Framework Convention and through the "à la carte system" introduced under Part III of the Languages Charter. The rest of this article therefore focuses on the UK's response.

\section{The UK's Experiences in relation to Irish-Language Education in Northern Ireland}

The Framework Convention was opened for signature on 1 February 1995 and was ratified by the UK on 15 January 1998, coming into force on 1 May of that year. ${ }^{86}$ The Languages Charter was opened for signature on 5 November 1992 but took much longer to come into force ${ }^{87}$ and was only ratified by the UK on 27 March $2001 .{ }^{88}$ Pentassuglia has suggested that delays in ratification might be attributed to the need for time to choose the most appropriate options for the languages spoken within a particular territory and/or to address positively the wider legal and political implications of ratification. ${ }^{89}$ These explanations are certainly supported by

82 Paras.6 and 8.

83 'Explanatory report', supra n.47 at para.71.

84 UN Working Group on Minorities 'Montreal International Seminar on Intercultural and Multicultural Education' (31 March 2000) UN Doc. E/CN.4/Sub.2/AC.5/2000/WP.4 at para.6.

85 Thornberry, 'Article 12' in Weller (ed.), supra n.11, p.365

86 Supra n.9.

87 Supra n.32.

88 'European Charter for Regional or Minority Languages CETS No.: 148' http://conventions.coe.int/Treaty/Commun/ChercheSig.asp?NT=148\&CM=7\&DF $=2 / 2 / 2007 \& C L=E N G(2$ February 2007).

89 Pentassuglia, Minorities in International Law (2002), p.131. 
the UK's experience with considerable debate over the languages to be included and the options to be selected. At one time it was envisaged that Irish would only be protected under Part II of the Charter ${ }^{90}$ but upon ratification the UK declared that it recognised Scots and Ulster-Scots as regional or minority languages for the purposes of Part II and that Welsh, Scottish-Gaelic and Irish would be protected under Part III. The UK subsequently declared that Part II would also apply to the Cornish and ManxGaelic languages. ${ }^{91}$

The provisions chosen for Irish were selected by an inter-departmental steering group coordinated by the Department of Culture, Arts and Leisure in Northern Ireland, ${ }^{92}$ whose minimal approach has been criticised by the Northern Ireland Human Rights Commission. ${ }^{93}$ In relation to pre-school, primary, secondary and technical and vocational education and Irish, the UK merely undertook to apply one of the measures identified to those pupils or whose families so wished and whose number is considered sufficient. ${ }^{94}$ This compares unfavourably with its undertakings to make pre-school, primary and secondary education available in both Welsh and Scottish-Gaelic. ${ }^{95}$ Dunbar has argued that, in view of similarities in the situation of ScottishGaelic and Irish and the development of Irish-medium education in Northern Ireland, it would have been appropriate to make the same designations for Irish as for the other two languages. ${ }^{96}$ In relation to higher education, the UK undertook "to encourage and/or allow" the provision of such education in regional or minority languages "or of facilities for the study of these languages as university or higher education subjects". It also undertook to offer Irish as a subject of adult or continuing education; to make arrangements to ensure the teaching of the history and the culture reflected by the Irish language; to provide the training of teachers required to implement its chosen options and "to allow, encourage or provide teaching in or of the regional or minority language" in respect of territories other than those in which the language is traditionally used. ${ }^{97}$

90 Dunbar 'Implications of the European Charter for Regional or Minority Languages for British Linguistic Minorities' (2000) 25 EL Rev (Supp) 46, at 65.

91 Declaration contained in a Note Verbale from the Foreign and Commonwealth Office of the United Kingdom, handed at the time of deposit of the instrument of ratification on 27 March 2001; Declaration contained in a letter from the Permanent Representative of the United Kingdom, dated 11 March 2003 and Declaration contained in a letter from the Permanent Representative of the United Kingdom, dated 22 April 2003 ('List of declarations made with respect to treaty No.: 148', http://conventions.coe.int/Treaty/Commun/ListeDeclarations.asp?NT $=148 \& \mathrm{CM}=7 \& \mathrm{DF}=2 / 6 / 2007 \& \mathrm{CL}=\mathrm{ENG} \& \mathrm{VL}=1$ (6 February 2007)).

92 Martin, 'The charter at work - the role of regional and local authorities' in Council of Europe Publishing (ed.) From Theory to Practice - the European Charter for Regional or Minority Languages (2002) pp.63 at 64.

93 NIHRC, supra n.31 at para.5(e).

94 Supra n.91.

95 ibid.

96 Dunbar 'Working Papers 10: The ratification by the United Kingdom of the European Charter for Regional or Minority Languages' (2003) http://www. ciemen.org/mercator/pdf/WP10-def-ang.pdf (2 February 2007), p.52.

97 Supra n.91. 
Whilst the ratification instrument lacked "normative ambition" in relation to Irish, equally important has been the extent of the UK's engagement with the relevant monitoring procedures. The monitoring procedures under both treaties are fairly similar with State reports to be submitted every five years under the Framework Convention ${ }^{98}$ and every three years under the Languages Charter. ${ }^{99}$ State reports are considered by independent experts within the Advisory Committee established under the Framework Convention and within the Committee of Experts established under the Charter. The findings of these committees are then transmitted to the Committee of Ministers, which adopts its own conclusions about the adequacy of the measures taken. It is now standard procedure for both committees to receive and invite information from sources other than States and to visit States whose reports are being considered, when their members will meet with a range of different actors and also visit minority areas. States are also given an opportunity to comment on their findings before the Committee of Ministers considers all the relevant documentation. ${ }^{100}$ The Advisory Committee under the Framework Convention in particular has placed considerable emphasis on the need to develop an on-going dialogue with States and a number of follow-up seminars with representatives from government bodies, national minorities and the Advisory Committee in order to consider the most appropriate ways of translating the findings into action have taken place. ${ }^{101}$

The UK's first report under the Framework Convention was submitted on 26 July $1999,{ }^{102}$ the Advisory Committee adopted its Opinion on 30 November $2001^{103}$ and the Committee of Ministers' Resolution followed on 13 June 2002. ${ }^{104}$ The UK's delay in ratifying the Languages Charter meant that its initial report under that treaty was considered much later. The UK's first report was submitted on 1 July 2002,,$^{105}$ the Committee of Experts adopted its

98 Committee of Ministers 'Rules on the monitoring arrangements under Articles 24 to 26 of the Framework Convention for the Protection of National Minorities', Resolution(97)10 of 17 September 1997, Rule 21.

99 Art. 15.

${ }^{100}$ For further information about the Advisory Committee's role, see Art. 26 of the Framework Convention, 'Rules of Procedure of the Advisory Committee on the Framework Convention for the Protection of National Minorities' ACFC/INF(1998)002 (29 October 1998) and 'Fourth Activity Report covering the period from 1 June 2002 to 31 May 2004' ACFC/INF(2004)001 (1 June 2004). On the role of the Committee of Experts, see Arts. 15-17 of the Charter and 'Monitoring the application of the European Charter for Regional or Minority Languages'

http://www.coe.int/T/E/Legal_Affairs/Local_and_regional_Democracy

/Regional_or_Minority_languages/2_Monitoring/About_Monitoring.asp\#TopOfP age (2 February 2007).

101 'Fourth Activity Report', supra n.100 at para.19.

102 'Report submitted by the United Kingdom', supra $\mathrm{n} .53$.

103 'Opinion on the United Kingdom' ACFC/INF/OP/I(2002)006 (30 November 2001) at paras.2-3.

$104 \operatorname{ResCMN}(2002) 9$.

105 'Initial Periodic Report presented to the Secretary General of the Council of Europe in accordance with Art. 15 of the Charter: United Kingdom' MINLANG/PR(2002)5 (1 July 2002), p.2. 
Report on 29 August 2003, ${ }^{106}$ almost two years after the report adopted by the Advisory Committee under the Framework Convention, and the Committee of Ministers concluded the reporting cycle with the adoption of its recommendation on 24 March 2004. ${ }^{107}$ Given the potential overlap in the jurisdiction of the relevant monitoring bodies, the differences in timing appeared advantageous. However, the rest of this section argues that the two treaties have played very different roles in relation to the protection of indigenous and non-indigenous languages in the UK.

\section{(a) The UK's Experiences under the Framework Convention}

The UK's initial report under the Framework Convention addressed the situation of a range of linguistic, religious and immigrant minorities, despite the apparent limitations of its definition of the term "racial group". ${ }^{108}$ However, the report itself was drafted by officials of the Home Office's Race Equality Unit in consultation with other parts of Government and NGOs. ${ }^{109}$ This clearly influenced the content of the report. For example, the main focus under Article 12 was on the provision made for the education of children from ethnic minority groups. ${ }^{110}$ The Advisory Committee's main findings in respect of that article subsequently concerned the low attainment levels, disproportionately high number of exclusions and underrepresentation in higher education of certain groups of ethnic minority pupils, as well as the low attendance levels of Roma/Gypsy and Irish Traveller children rather than the fostering of knowledge of minority languages, history and culture. ${ }^{111}$ This can be contrasted with the recommendations made to other States that have limited the Framework Convention's scope of application to specified autochthonous groups. ${ }^{12}$

The stance adopted in the UK's report was that it would not be practicable to provide teaching of the national curriculum in the variety of mother-tongues represented in the $\mathrm{UK}^{113}$ and the main focus under Article 14 was therefore on the provision of State support for Welsh, Scottish-Gaelic and Irishmedium education. ${ }^{114}$ The Advisory Committee welcomed the increasing possibilities for receiving education in all three languages ${ }^{115}$ but also referred specifically to representations it had received from Irish-language speakers "that more could be done to support Irish language education, including at the level of higher education where no such possibility exists" 116 and from

106 'Report of the Committee of Experts on the Application of the Charter in the United Kingdom' ECRML(2004)1 (made public on 24 March 2004).

$107 \operatorname{RecChL}(2004) 1$.

108 'Report submitted by the United Kingdom', supra n.53.

109 'Memorandum to the Joint Committee on Human Rights from Michael Wills MP, January 2002' Annex B, at para.7(b).

110 'Report submitted by the United Kingdom', supra n.53 at paras.172-190.

111 'Opinion on the United Kingdom', supra n.103 at paras.120-123.

112 On the Advisory Committee's practice under Art. 12, see Thornberry, supra n.85 at pp.376-386 and Advisory Committee 'Commentary on Education under the Framework Convention for the Protection of National Minorities' ACFC/25DOC(2006)002 (2 March 2006) chap.2.1.2.

113 'Report submitted by the United Kingdom', supra n.53 at para 193.

114 ibid. at paras. 193-203.

115 “'Opinion on the United Kingdom', supra n.103 at para. 92.

116 ibid. 
Ulster-Scots speakers, who wanted to see the teaching of the Ulster-Scots language and literature introduced in schools. ${ }^{117}$ Its overall conclusion therefore was that "further support is needed, in particular, for Irish language education and that the situation of Ulster Scots also needs to be examined" and "that the United Kingdom should examine with those concerned further measures that could be taken in support of such education."118 Although not a particularly strong recommendation, it is fairly typical of the recommendations made to other States under Article 14 and reflects the weak wording of the provision itself. ${ }^{119}$ However, it does not appear that the situation of Irish was considered in any real depth and the Advisory Committee focused most of its attention instead on the situation of ethnic minority languages, ${ }^{120}$ recommending also that the UK "further assess the level and variety of language needs of the ethnic minority communities". ${ }^{121}$

The UK's initial response to the Advisory Committee's opinion was quite positive, noting that further measures had been taken to encourage and facilitate Irish-medium education, including the establishment and funding of a new body to promote Irish-language education, Comhairle na Gaelscolaiochta, and a reduction in viability criteria for grant-aid for new primary and secondary schools. However, its response in relation to UlsterScots was that there was no similar demand from parents for access to education in "Ulster-Scots-medium schools", apparently missing the point that this was not what was being sought by the representatives in contact with the Advisory Committee, whose requests related to the teaching of the Ulster-Scots language and literature. ${ }^{122}$ As is standard procedure, the Committee of Ministers recommended that appropriate account be taken both of its conclusions and the Advisory Committee's opinion and invited the Government to continue "the dialogue in process" with the Advisory Committee and to keep that body "regularly informed" of the measures taken in response. ${ }^{123}$ The UK's subsequent engagement with the Advisory Committee has been disappointing. The UK notably did not organise a follow-up seminar after the conclusion of the first monitoring cycle ${ }^{124}$ and the UK's second report, due on 1 May 2004, was only submitted on 22 February

117 ibid.

118 ibid., at para 125.

119 On the practice under Art.14, see Wilson, 'Report: A critical evaluation of the first results of the monitoring of the Framework Convention on the issue of minority rights in, to and through education (1998-2003)' in Council of Europe (ed), Filling the Frame: Five Years of Monitoring the Framework Convention for the Protection of National Minorities (2004) p.163 at pp.184-189 and 'Commentary on Education', supra n.112, chap.2.3.2.

120 'Opinion on the United Kingdom', supra n.103 at paras.89-91 (on ethnic minority languages) and para. 92 (on the indigenous languages).

121 ibid., para. 124.

122 'Comments of the Government of the United Kingdom on the Opinion of the Advisory Committee on the Implementation of the Framework Convention for the Protection of National Minorities in the United Kingdom' GVT/COM/INF/OP/I(2002)06 (18 April 2002) at para.125.

123 ResCMN(2002)9, at paras.2 and 3.

124 'Fourth Activity Report', supra n.100, Appendix 2. 
2007. ${ }^{25}$ This delay can be at least partly attributed to the logistical challenges of producing a report that deals with such a wide range of minority groups as well as to continuing debates over which groups should come within its scope of application. ${ }^{126}$

\section{(b) The UK's Experiences under the Languages Charter}

Whereas the UK's decision to adopt a broad stance on the definitional issue under the Framework Convention meant that it was perhaps inevitable that the situation of Irish would not be considered in much depth by the Advisory Committee, the situation under the Charter was quite different. The particular significance of the Languages Charter for the development of Irish-medium education in Northern Ireland was recognised from the outset $^{127}$ and information for the UK's initial report was provided by the devolved institutions. ${ }^{128}$ This included information on the reduction of viability criteria for Irish-medium primary schools to obtain recurrent grantaid $^{129}$ and about the provision of funding from the Irish-language agency for a voluntary support organisation for Irish-medium schools, teaching and learning resources and for schools awaiting departmental recognition as well as to a voluntary organisation for special-needs in Irish-medium education. ${ }^{130}$ Significantly, the Committee of Experts' visit to the UK included a visit to Northern Ireland and meetings were held with representatives of the Northern Ireland Assembly and the Ulster-Scots and the Irish-language agencies as well as representatives of associations promoting the use of minority languages. ${ }^{131}$

In relation to Part II of the Charter, the Committee of Experts noted that the official position was that there was no demand for the teaching of the UlsterScots language but expressed the view that "a lack of demand is often due to a lack of supply". ${ }^{132}$ It therefore suggested that the authorities consider taking initiatives in that area. ${ }^{133}$ In relation to Irish, the view of the Committee of Experts was that most of the undertakings made had been fulfilled ${ }^{134}$ but that it did not have enough information to conclude whether the undertakings in relation to vocational training ${ }^{135}$ and territories other than

125 'List of State Reports $2^{\text {nd }}$ Cycle' http://www.coe.int/t/e/human_rights/minorities/ 2._framework_convention_(monitoring)/2._monitoring_mechanism/3._state_repo rts_and_unmik_kosovo_report/2._second_cycle/List_SR_2nd_cycle.asp\#TopOfP age (1 June 2007).

126 See report drafted for the consideration of the Advisory Committee 'The Cornish and the Council of Europe Framework Convention for the Protection of National Minorities' http://www.geecee.co.uk/CNMR/ (2 February 2007).

127 Supra n.7.

128 'Initial Periodic Report presented to the Secretary General of the Council of Europe in accordance with Article 15 of the Charter: United Kingdom' MINLANG/PR(2002)5 (1 July 2002), p.2.

129 ibid., at 48.

130 ibid.

131 'Report of the Committee of Experts on the Application of the Charter in the United Kingdom' ECRML(2004)1 (24 March 2004) at para.6.

132 ibid., at para.68.

133 ibid.

134 ibid., at paras.307, 310, 312, 319, 325, 326 and 330.

135 ibid.. at para. 316. 
those in which Irish was used had been fulfilled. ${ }^{136}$ The Committee of Experts' overall assessment was that steps were being taken to improve the situation of Irish but, as the situation was developing rapidly and sufficient information had not always been available, it concluded that it would be difficult to propose any concrete recommendations. ${ }^{137}$ It noted in particular that, although positive steps had been taken in the field of education, more needed to be done "in terms of coherent policy-making and planning, including the allocation of adequate resources". ${ }^{138}$ The Committee of Ministers did not subsequently make any recommendations in relation to Irish-language education. ${ }^{139}$ However, it did recommend that the authorities take account of the observations of the Committee of Experts and, "as a matter of priority: 1. make primary and secondary education in Scottish Gaelic generally available in the areas where the language is used". ${ }^{140}$ This provides an indication of the significance of the greater "normative ambition" shown in the instrument of ratification in relation to ScottishGaelic.

Whilst the lack of concrete recommendations in relation to Irish-language education appears disappointing, the Committee of Experts at least reached its conclusions after a thorough examination of the current position with particular account taken of the views of NGOs representing Irish-language speakers and the Irish-language agency. ${ }^{141}$ This compares favourably with the much more cursory examination adopted by the Advisory Committee, which had to focus on a much wider range of minority groups and on a broader range of minority issues. It also highlights the benefits of the State visits and meetings with minority representatives, which form an important part of the work of both the Advisory Committee and the Committee of Experts and can be favourably contrasted with the more passive approach adopted by the UN treaty-monitoring bodies. In the main body of its report, the Committee of Experts referred specifically to concerns from NGOs about a lack of sufficient teaching materials in Irish ${ }^{142}$ and the enrolment criteria for Irish-medium pre-schools. ${ }^{43}$ It also noted that reference had been made to the challenges of ensuring the training of a sufficient number of teachers to keep up with demand for Irish-medium education. ${ }^{144}$ In so doing, it appeared to highlight areas where improvements could be made and which might be subject to further investigation in the next reporting cycle, emphasising the importance of continuing to improve the situation of minority languages within States.

136 ibid.. at para.331.

137 ibid.. Chapter 3F.

138 ibid.. Chapter $3 \mathrm{G}$.

139 Recommendation RecChL(2004)1 on the Committee of Ministers on the application of the European Charter for Regional or Minority Languages by the United Kingdom (24 March 2004).

140 ibid.. at para.1.

141 'Report of the Committee of Experts on the Application of the Charter in the United Kingdom', supra n.131 at paras.302-331.

142 ibid.. at para. 305

143 ibid.. at para.307.

144 ibid., at para.329. 
The reporting cycle under the Languages Charter is shorter than under the Framework Convention and the UK's second report was submitted promptly, just over a year after the end of the first reporting cycle on 1 July 2005 . $^{145}$ Both the Irish-language and Ulster-Scots agencies were consulted on the Northern Ireland contribution to the report ${ }^{146}$ and, as no specific recommendations had been made in relation to Irish-language education, no information was needed on the UK's response. ${ }^{147}$ Nevertheless some important developments were noted. For example, it was reported that Ulster-Scot primary and secondary school materials were being developed at Stranmillis University College, ${ }^{148}$ that an Irish-medium Unit had been established by the Council for the Curriculum Examinations and Assessment to translate examination and assessment materials ${ }^{149}$ and that an IrishMedium Curriculum Materials Unit had been established at St Mary's University College. ${ }^{150}$ It was also noted that there had been an increase in the number of Irish-medium primary schools with grant-aided status to 19 (with 10 Irish-medium units within existing schools) ${ }^{151}$ and an increase in the number of pupils studying Irish as a second language at GCSE level. ${ }^{152}$ Reference was also made to the continuation of funding for Irish-language vocational training programmes for those leaving Irish-medium secondary education at $16^{153}$ and to developments in the area of teacher-training. ${ }^{154}$ Meanwhile another important initiative reported was the establishment in Northern Ireland of an Interdepartmental Charter Implementation Group with responsibility "for coordinating work to implement, monitor and report on the Charter." 155 It therefore appears that there have been a number of positive developments in this area since the UK ratified the Charter, despite the lack of concrete recommendations from the Committee of Experts. These may be partly attributable to the effective use of the Charter as lobbying tool and the next section explores further the profile of both treaties at the domestic level.

145 'Second Periodic Report presented to the Secretary General of the Council of Europe in accordance with Article 15 of the Charter: United Kingdom' MINLANG/PR(2005)5 (1 July 2005).

146 ibid., at 18. See also 'Second UK Report on Compliance with the European Charter for Regional or Minority Languages: Northern Ireland Contribution, June 2005 http://www.dcalni.gov.uk/Contman/includes/upload/file.asp?ContentID= $1063 \&$ file $=$ c_24 (2 February 2007).

147 States are asked to summarise the measures for each recommendation in their periodic reports ('The European Charter for Regional or Minority Languages: Outline for three-yearly Periodic Reports to be submitted by Contracting Parties' MIN-LANG(2002)1 (7 February 2002) Part I, Q 5).

148 'Second Periodic Report', supra n.145 at 37.

149 ibid., at 38.

150 ibid., at 63.

151 ibid., at 62.

152 ibid., at 63 .

153 ibid., at 64.

154 ibid., at 65 .

155 ibid., at 5. 


\section{Recent Developments at Domestic Level}

Although the Council of Europe's minority treaties do not have as high a profile as the UN human rights treaties in the UK as a whole, ${ }^{156}$ the situation is rather different in Northern Ireland. Both the Framework Convention and the Languages Charter were mentioned in the Good Friday Agreement ${ }^{157}$ and have influenced debates over future legislative developments, in particular in relation to proposals for a Bill of Rights and for an Irish Language Act. In relation to the former, there has been some discussion about the possible incorporation of the Framework Convention into domestic law ${ }^{158}$ with debate over whether members of the Protestant majority should be entitled to protection under the Framework Convention and whether use of the term "community" is preferable to the term "minority". 159 As the UK has not restricted the scope of application of the Framework Convention to indigenous minorities, it is perhaps unsurprising that it has been proposed that some of the rights in the Framework Convention should be applied in relation to all linguistic minorities. ${ }^{160}$ These include the right "to be educated in and through their language, where there are sufficient numbers of users and sufficient demand". ${ }^{161}$ Although it has been recognised that sufficiency of demand already exists in relation to the Irish, it has also been suggested that this might develop over time in relation to other languages. ${ }^{62}$ It therefore appears that the provisions of the Framework Convention, as a human rights treaty, are considered to be relevant to a range of linguistic groups and not just the indigenous minorities.

It was also proposed by the Northern Ireland Human Rights Commission that legislation be introduced specifically to implement the UK's commitments under the Charter in relation to the Irish language and Ulster-Scots. ${ }^{163}$ Meanwhile legislative proposals for an Irish Language Act have been drafted by POBAL, the umbrella organisation for the Irish-language community, and include recognition of a right of parents to have their children receive Irishmedium education and to be taught the Irish language at all stages of primary and post-primary education. ${ }^{164}$ The proposals also envisage the imposition of more specific obligations on the Department of Education in relation to the development of Irish-medium education, the teaching of the Irish language in

156 For example, the Joint Committee on Human Rights now routinely produces reports for Parliament on the UK's obligations under the UN human rights treaties.

157 'Good Friday Agreement', supra n.6 'Human Rights' para.9 and 'Economic, Social and Cultural Issues' para.4.

158 NIHRC 'Making a Bill of Rights for Northern Ireland - Consultation Document. September 2001' chap.13 and NIHRC 'Progressing a Bill of Rights for Northern Ireland: An Update. April 2004' s. 14. These documents can be found on the Bill of Rights section of the NIHRC's website at 'Consultation Documents' http://www.nihrc.org/index.php?option=com_content\&task=view\&id=54\&Itemid $=71$ ( 2 February 2007).

159 McCrudden, supra n.13.

160 Supra n.158.

161 'Progressing a Bill of Rights for Northern Ireland', supra n.158, s.14(3).

162 'Making a Bill of Rights for Northern Ireland', supra n.158 at p.78.

163 'Progressing a Bill of Rights for Northern Ireland', supra n.158, s.14 (4).

164 'POBAL's Proposals for The Irish language Act Northern Ireland' (February 2006) Pt III, s.42 http://www.pobal.org/english/docs/act.pdf (2 February 2007). 
English-medium schools, the development and provision of teaching materials, assessment tools and the curriculum and teacher training. ${ }^{165}$ The drafters were clearly influenced by the requirements of the Charter and this reinforces the overall impression that the two treaties have very different roles in relation to the protection of indigenous and other languages. ${ }^{166}$ It is particularly significant that the idea of an Irish Language Act has now acquired official support with the St Andrews Agreement of 13 October 2006, which also improves the future prospects of the Bill of Rights project. ${ }^{167}$

\section{Conclusion}

Despite some substantive overlap and similar monitoring procedures, this article has argued that the Framework Convention and the Languages Charter have very different roles in relation to the protection of indigenous and non-indigenous languages in the UK. These different roles can be attributed not only to the UK's decision to adopt a broad definition of the term "national minority" but also to the role of the Framework Convention as a human rights treaty, which has clearly influenced both the wording of the substantive provisions on education and the decision of the Advisory Committee to focus on educational issues impacting on a range of minority groups. Although most States have adopted a narrower approach on the definitional issue, the UK's experiences provide an illustration of how the requirements of the Framework Convention can be applied in relation to immigrant minorities. ${ }^{168}$ The Languages Charter specifically excludes migrant languages from its scope of application and imposes more concrete and precise obligations on ratifying States. It has been noted that the usefulness of the Charter's "à la carte system" depends to a large extent on the "normative ambition" shown by States Parties ${ }^{169}$ and the UK's cautious response to the selection of provisions was perhaps disappointing. Nevertheless there have been a number of positive developments in relation to Irish-language education since the Charter came into force and the UK has so far engaged to a greater extent with the monitoring procedures under the Charter than with those developed under the Framework Convention. However, there remain concerns that insufficient measures have been taken to meet increased demand for Irish-medium education in Northern Ireland, ${ }^{170}$ and this is reflected in the more critical stance adopted at the end of the

165 ibid., s.45.

166 The experts consulted included Robert Dunbar, who has written extensively on the Charter (supra nn.12, 54, 90 and 96).

167 Annex B included a commitment to establish a forum on a Bill of Rights and to introduce an Irish Language Act.

168 As Wheatley has noted, States are permitted but not required to exclude "new minorities" from its scope of application and the Advisory Committee has consistently encouraged States to widen its scope of application to cover a wider range of minority groups (Wheatley, supra $\mathrm{n} .50$ at pp.48-56).

169 Oeter, supra n.11, at pp.147-148.

170 (POBAL 'The European Charter for Regional or Minority Languages: The Implementation of the Charter with Regard to the Irish Language 2002-5' at paras.5.37-5.50 http://www.pobal.org/english/docs/tua.cairt.b.pdf (2 February 2007). 
Irish-Language Education and the Council of Europe's Minority 141

second monitoring cycle. ${ }^{171}$ The committee of experts therefore has an important role to play in continuing to monitor developments in this area.

171 Although the Committee of Experts adopted its second evaluation report on the UK on 14 September 2006, the contents have only just been made public ('Monitoring the implementation of the European Charter for Regional or Minority Languages' http://www.coe.int/t/e/legal_affairs/local_and_regional_ democracy/regional_or minority_languages/2_Monitoring/Monitoring_table.asp \#TopOfPage (1 June 2007)). 